\title{
Phytoprotection
}

\section{Seasonal occurrence of three Lepidoptera on broccoli and effectiveness of planting date as a pest management tool in southeastern New Brunswick \\ Développement saisonnier de trois lépidoptères associés au brocoli et efficacité de la date de mise en terre comme outil dans un programme de gestion d'insectes nuisibles dans le sud-est du Nouveau-Brunswick.}

\author{
P.M. Maltais, J.R. Nuckkle et P.V. LeBlanc
}

Volume 79, numéro 3, 1998

URI : https://id.erudit.org/iderudit/706141ar

DOI : https://doi.org/10.7202/706141ar

Aller au sommaire du numéro

Éditeur(s)

Société de protection des plantes du Québec (SPPQ)l

ISSN

0031-9511 (imprimé)

1710-1603 (numérique)

Découvrir la revue

Citer cet article

Maltais, P., Nuckkle, J. \& LeBlanc, P. (1998). Seasonal occurrence of three Lepidoptera on broccoli and effectiveness of planting date as a pest management tool in southeastern New Brunswick. Phytoprotection, 79(3),

129-137. https://doi.org/10.7202/706141ar

\section{Résumé de l'article}

L'abondance saisonnière de trois lépidoptères ravageurs du brocoli (Brassica oleracea var. italica), la fausse-teigne des crucifères, Plutella xylostella [Lepidoptera : Plutellidae], la piéride du chou, Pieris rapae [Lepidoptera : Pieridae], et la fausse-arpenteuse du chou, Trichoplusia ni [Lepidoptera : Noctuidae], a été étudiée pendant deux années dans le sud-est du Nouveau-Brunswick. Quatre générations de la piéride du chou ont été observées en 1990 et en 1991 avec 92 et $99 \%$, respectivement, de la population larvaire totale présente après le 23 juillet. Quatre générations de la fausse-teigne des crucifères ont aussi été observées durant la même période avec 81 et $97 \%$, respectivement, de la population larvaire totale présente après le 23 juillet de chacune des années. Les populations de la fausse-arpenteuse du chou sont apparues plus tard dans la saison et à cause de leur faible abondance ont été plus difficiles à évaluer. En utilisant l'équivalent de la fausse-arpenteuse du chou (EDFAC), nous avons étudié l'efficacité de la date de mise en terre comme outil de gestion des populations nuisibles. Les plants mis plus tôt en terre supportent des populations avec un EDFAC moyen par plant par semaine plus faible et exigent moins d'insecticide pour la lutte contre ces insectes. 


\title{
Seasonal occurrence of three Lepidoptera on broccoli and effectiveness of planting date as a pest management tool in southeastern New Brunswick
}

\author{
Patrick M. Maltais ${ }^{1}$, Jacques R. Nuckle1, and Paul V. LeBlanc ${ }^{2}$
}

Received 1998-10-08; accepted 1999-01-11

PHYTOPROTECTION 79 : 129-137

Seasonal variations in abundance of three lepidopterous pests, the diamondback moth, Plutella xylostella [Lepidoptera: Plutellidae], the imported cabbageworm, Pieris rapae [Lepidoptera : Pieridae], and the cabbage looper, Trichoplusia ni [Lepidoptera : Noctuidae], were monitored over two years in broccoli plantings (Brassica oleracea var. italica) in southeastern New Brunswick. Four population peaks of imported cabbageworm were seen in 1990 and 1991 with 92 and 99\% of the total larval population, respectively, being recorded during the latter part of the season, after 23 July. Four population peaks were also recorded for the diamondback moth in 1990 and 1991 with 81 and 97\%, respectively, of the population being recorded after 23 July. Populations of cabbage looper appeared later in the season and because of low numbers were more difficult to assess. Using cabbage looper equivalents (CLE), the effectiveness of planting date as a pest management tool was also studied. Early crops have lower mean CLE per plant per week, and would require less insecticide applications than later crops.

[Développement saisonnier de trois lépidoptères associés au brocoli et efficacité de la date de mise en terre comme outil dans un programme de gestion d'insectes nuisibles dans le sud-est du Nouveau-Brunswick]

L'abondance saisonnière de trois lépidoptères ravageurs du brocoli (Brassica oleracea var. italica), la fausse-teigne des crucifères, Plutella xylostella [Lepidoptera : Plutellidae], la piéride du chou, Pieris rapae [Lepidoptera : Pieridae], et la fausse-arpenteuse du chou, Trichoplusia ni [Lepidoptera : Noctuidae], a été étudiée pendant deux années dans le sud-est du Nouveau-Brunswick. Quatre générations de la piéride du chou ont été observées en 1990 et en 1991 avec 92 et $99 \%$, respectivement, de la population larvaire totale présente après le 23 juillet. Quatre générations de la fausseteigne des crucifères ont aussi été observées durant la même période avec 81 et $97 \%$, respectivement, de la population larvaire totale présente après le 23 juillet de chacune des années. Les populations de la fausse-arpenteuse du chou sont apparues plus tard dans la saison et à cause de leur

1. Département de biologie, Faculté des sciences, Université de Moncton, Moncton, New Brunswick, Canada E1A 3E9

2. Agriculture and Agri-Food Canada, Senator Hervé J. Michaud Experimental Farm, Box 667, Bouctouche, New Brunswick, Canada EOA 1G0 
faible abondance ont été plus difficiles à évaluer. En utilisant l'équivalent de la fausse-arpenteuse du chou (EDFAC), nous avons étudié l'efficacité de la date de mise en terre comme outil de gestion des populations nuisibles. Les plants mis plus tôt en terre supportent des populations avec un EDFAC moyen par plant par semaine plus faible et exigent moins $d^{\prime}$ insecticide pour la lutte contre ces insectes.

\section{INTRODUCTION}

The diamondback moth, Plutella xylostella (L.) [Lepidoptera: Plutellidae], the imported cabbageworm, Pieris rapae (L.) [Lepidoptera: Pieridae], and the cabbage looper, Trichoplusia ni (Hübner) [Lepidoptera: Noctuidae], are pests of cruciferous crops in many parts of the world including the province of New Brunswick, Canada, where broccoli (Brassica oleracea L. var. italica Plenck) is grown for the fresh market. Foliar feeding by these pests early in the season only impacts indirectly on yield because the inflorescence (head), the marketable product, is produced in the last $15 \mathrm{~d}$ of growth. Although they can physically damage the inflorescence during heading, contamination (frass, exuviae, living and dead larvae or pupae) is of greater economic importance (Vail et al. 1989).

According to Lasota and Kok (1989), the relative importance of each species varies with location. This has been shown in studies of seasonal occurrence (Andaloro et al. 1982; Godin and Boivin 1998; Hamilton 1979; Harcourt et al. 1955; Lasota and Kok 1989) or through the development of pest management techniques on various cole crops (Cranshaw and Default 1985; Hoy et al. 1986; Maltais et al. 1994, 1998; Sears et al. 1983, 1985; Stewart and Sears 1988; Vail et al. 1989).

Pest management strategies for cole crops are currently lacking in New Brunswick. Growers still rely on applications of insecticides at regular intervals to control insects. A better understanding of the seasonal occurrence and abundance of the individual species during the growing season is required to initiate a management program for this lepidopterous complex on broccoli and other cole crops in this province.
The objectives of this study were to determine the seasonal occurrence and abundance of the imported cabbageworm, the diamondback moth, and the cabbage looper on broccoli in southeastern New Brunswick, and to determine if late plantings are more at risk from this complex than early plantings.

\section{MATERIALS AND METHODS}

The experiment was conducted at the Agriculture and Agri-Food Canada Senator Hervé J. Michaud Research Farm (lat. $46^{\circ} 26^{\prime} \mathrm{N}$, long. $64^{\circ} 46^{\prime} \mathrm{W}$ ), Bouctouche, New Brunswick, Canada. 'Emperor' broccoli seedlings ( 4 wk-old) were transplanted on 28 May, 22 June and 11 July 1990 and on 29 May, 4 July and 16 July 1991. Plots were kept free of pesticides except for an application of fensulfothion (Dasanit 720 Soluble Concentrate [SC]; Chemagro Ltd., Mississauga, Ontario) at a rate of $1.8 \mathrm{~kg}$ a.i. $\mathrm{ha}^{-1}$ at planting against root maggots. In 1990, 22 broccoli seedlings per row were planted in four plots per planting date, with $35 \mathrm{~cm}$ between plants, with four rows per plot and $1 \mathrm{~m}$ between rows. In 1991, eight-row plots were used per planting date with 14 plants per row with the same spacings as in 1990. Lepidopterous pests were counted twice a wk in 1990 from 5 June to 27 August using a non-destructive 10-plant-perplot sample for a total of 1474 plants. In 1991, 10 plants per plot were randomly sampled once a wk from 5 June to 18 September, except for the 16 July planting where eight plants per plot were sampled on each date, for a total of 702 plants. The species and life stages counted were: diamondback moth, imported cabbageworm and cabbage looper; eggs, larvae and pupae.

Since the three species do not have the same feeding rate or cause the same 
amount of damage, population numbers were transformed into cabbage looper equivalents (CLE) based on work done by Harcourt et al. (1955) and modified by Stewart (1990). Foliage consumed was equated so that $1 \mathrm{CLE}=$ 1 cabbage looper $=1.5$ imported cabbageworm $=5$ diamondback moth larvae.

\section{RESULTS AND DISCUSSION}

\section{Seasonal activity and abundance}

\section{Imported cabbageworm}

During the 1990 growing season (28 May - 27 August), imported cabbageworm adults first oviposited by 5 June with a small peak of 0.48 eggs per plant, on average, on 18 June (Fig. 1a). A second peak of 2.45 eggs per plant, on average, was recorded on 29 July. When plants of the third planting were harvested on 27 August (Table 1), egg populations were still high with 2.98 individuals per plant (Fig. 1a). A total of 865 eggs or $79 \%$ of all eggs were recorded between 23 July and $27 \mathrm{Au}-$ gust 1990 from 514 plants for an average of 1.68 eggs per plant as compared to 224 eggs ( $21 \%$ ) from 960 broccoli for an average of 0.23 eggs per plant from 5 June to 20 July. Most eggs were laid on the underside of the broccoli leaves.

An average of 0.46 larvae per plant were found in 1990 (Table 2). Two relatively small peaks of 0.20 and 0.13 larvae per plant were observed on 18 June and 10 July, respectively (Fig. 1a). A third peak was observed on 29 July with an average of 0.93 larvae per plant and a fourth on 13 August with a density of 2.20 larvae per plant. Larval

Table 1. Dates of planting, monitoring start and harvest and mean number of cabbage looper equivalents (CLE \pm SD) per plant per week for each of the three broccoli plantings (P1, P2, P3) of 1990 and 1991, Bouctouche, NB

\begin{tabular}{|c|c|c|c|c|c|}
\hline \multirow{2}{*}{$\begin{array}{l}\text { Broccoli } \\
\text { planting }\end{array}$} & \multirow[b]{2}{*}{ Year } & \multicolumn{3}{|c|}{ Dates of } & \multirow[b]{2}{*}{$C L E \pm S D$} \\
\hline & & Planting & Monitoring start & Harvest & \\
\hline $\mathrm{P} 1$ & $\begin{array}{l}1990 \\
1991\end{array}$ & $\begin{array}{l}28 \text { May } \\
29 \text { May }\end{array}$ & $\begin{array}{l}5 \text { June } \\
5 \text { June }\end{array}$ & $\begin{array}{l}24 \text { July } \\
29 \text { July }\end{array}$ & $\begin{array}{l}0.166 \pm 0.05 \\
0.068 \pm 0.04\end{array}$ \\
\hline $\mathrm{P} 2$ & $\begin{array}{l}1990 \\
1991\end{array}$ & $\begin{array}{l}22 \text { June } \\
4 \text { July }\end{array}$ & $\begin{array}{l}25 \text { June } \\
10 \text { July }\end{array}$ & $\begin{array}{l}9 \text { August } \\
28 \text { August }\end{array}$ & $\begin{array}{l}0.471 \pm 0.03 \\
0.630 \pm 0.11\end{array}$ \\
\hline P3 & $\begin{array}{l}1990 \\
1991\end{array}$ & $\begin{array}{l}11 \text { July } \\
16 \text { July }\end{array}$ & $\begin{array}{l}16 \text { July } \\
23 \text { July }\end{array}$ & $\begin{array}{l}27 \text { August } \\
18 \text { September }\end{array}$ & $\begin{array}{l}1.223 \pm 0.07 \\
0.625 \pm 0.02\end{array}$ \\
\hline
\end{tabular}

Table 2. Mean number of insect pests per broccoli plant in southeastern New Brunswick, 1990 and 1991

\begin{tabular}{lllll}
\hline Insect pest & Year & Eggs & Larvae & Pupae \\
\hline Imported cabbageworm & 1990 & 0.74 & 0.46 & 0.001 \\
& 1991 & 0.76 & 0.72 & 0.006 \\
Diamondback moth & 1990 & 0.07 & 1.45 & 0.28 \\
& 1991 & 0.02 & 0.66 & 0.21 \\
Cabbage looper & 1990 & 0.003 & 0.02 & -- \\
& 1991 & 0.01 & 0.05 & -- \\
\hline
\end{tabular}

Sample size: 1474 plants in 1990, 702 plants in 1991. 

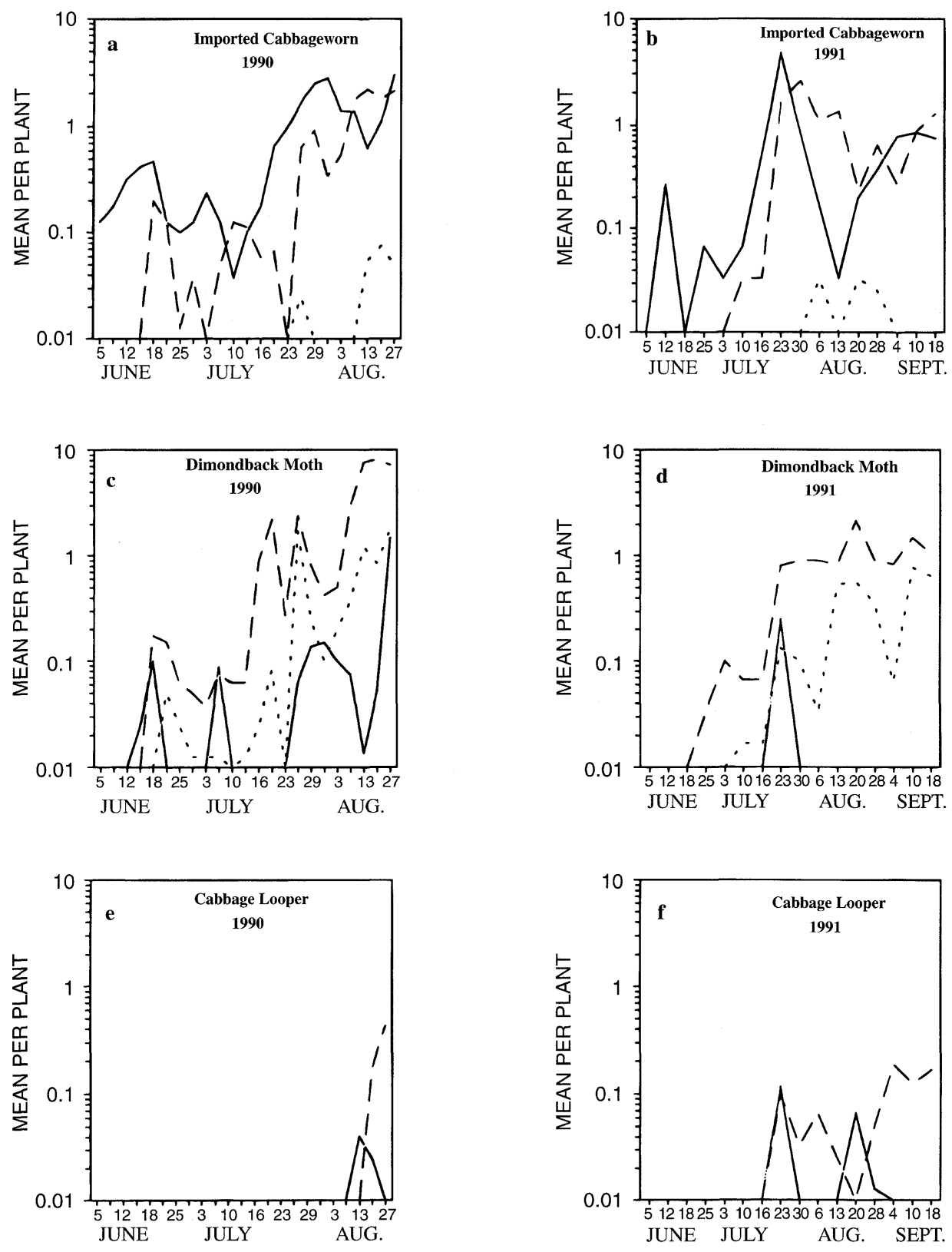

Figure 1. Seasonal abundance of imported cabbageworm $(a, b)$, diamondback moth (c, d), and cabbage looper $(e, f)$ eggs $(-)$, larvae $(--)$, and pupae $(. .$.$) in 1990$ and 1991 , with y axis logarithmically scaled. 
populations remained high thereafter. A total of 622 larvae (92\%) were recorded from 514 plants from 23 July to 27 August 1990, for an average of 1.21 larvae per plant. Only 55 larvae (8\%) were sampled from 960 plants for an average of 0.66 larvae per plant during the 5 June - 20 July period.

Small numbers of pupae were found on 26 July and from 13 August through 27 August (Fig. 1a) for an average of 0.001 pupae per plant for the season (Table 2).

By delaying harvest to 18 September, in 1991, we were able to observe the imported cabbageworm populations over the entire growing season. As in 1990, sampling began on 5 June. A total of 531 eggs were recorded for an average of 0.76 eggs per plant (Table 2). Except for a small peak on June 12 (0.27 eggs per plant), few eggs were seen before 23 July (4.68 eggs per plant) (Fig. 1b). Thereafter, oviposition remained low until a third peak of 0.85 eggs per plant was recorded on 10 September. A total of 485 eggs (91\%) were recorded between 23 July and 18 September from 432 broccoli, for an average of 1.12 eggs per plant. Only 46 eggs $(9 \%)$ from 270 plants, for an average of 0.17 eggs per plant, were recorded between 5 June and 16 July. Again, the majority of the eggs were laid on the underside of the broccoli leaves.

In 1991, no larvae were found before 10 July. Larval populations first peaked on 30 July with an average density of 2.58 larvae per plant (Fig. 1b). Thereafter, peaks occurred on 13 and 28 August with average larval populations of 1.37 and 0.64 individuals per plant, respectively. At harvest of the third planting, on 18 September, larval populations averaged 1.29 individuals per plant (Fig. 1b). A total of 502 imported cabbageworms (99\%) were recorded from 432 plants, for an average of 1.16 larvae per plant, from 23 July to 18 September. Only 4 larvae $(1 \%)$ were recorded from 270 broccoli, for an average of 0.01 larvae per plant, during the 5 June - 16 July period.

Only four pupae were seen in 1991 with all individuals recorded in August
(Fig. 1b) for an average of 0.006 pupae per plant for the season (Table 2).

Our studies of the egg, larval and pupal stages along with population trends suggest there are three to four generations of this lepidopteran pest on broccoli in southeastern New Brunswick. However, since adults are seen in mid-May and broccoli seedlings are transplanted from late May to early June or later in this province, the first generation of the imported cabbageworm must migrate from wild crucifers of surrounding areas or more southerly locations before moving onto cultivated plants. Lasota and Kok (1989) recorded two to three generations for this insect on cabbage in Virginia when plantings were available during the length of the growing season.

Broccoli plants, after harvest, will grow side shoots that can serve as a reservoir for the imported cabbageworm. Moreover, mature larvae will migrate to overwintering sites in the fall (Lasota and Kok 1989). New Brunswick growers often disk these residual plants into the soil soon after harvest. This practice has many beneficial effects for the growers and for insect management. Imported cabbageworm larvae, then, lose their source of food or are killed when disked into the ground with the plants or when they are migrating through the fields to overwintering sites. This reduction in the number of imported cabbageworms at the end of the growing season should have a direct effect on the following year's first generation thus making this pest easier to manage.

\section{Diamondback moth}

A total of 106 eggs were recorded in 1990 for an average of 0.07 eggs per plant (Fig. 1c; Table 2). Because of their small size, the number of eggs and early instars of the diamondback moth may have been underestimated.

Larvae were first noticed on 18 June and populations peaked on 20 July, 26 July and 13 August with averages of $2.18,2.39$ and 7,68 larvae per plant, respectively (Fig. 1c). A total of 1720 larvae $(81 \%)$ were recorded from 514 
broccoli, for an average of 3.35 larvae per plant, during the 23 July - 27 August period as compared to 410 larvae (19\%) from 960 broccoli, for an average of 0.43 larvae per plant, between 5 June and 20 July. Larval populations increased dramatically from 8 August to 27 August, with $67 \%$ of all 1990 diamondback moth larvae recorded during that $20 \mathrm{~d}$ period. The pupae, being easier to see, was more accurately sampled than the eggs and early instars. Peak pupal populations occurred on 26 July, 13 August and on 27 August 1990 after small numbers were recorded on 21 June and 20 July (Fig. 1c).

In 1991, diamondback moth populations were not as numerous as in 1990 even though the sampling period was extended three wk. Only 16 eggs, for an average of 0.02 eggs per plant, were recorded that yr (Table 2). The number of larvae was also lower in 1991 with 463 individuals recorded. In 1990, the larval population averaged 1.45 larvae per plant for the growing season while, in 1991, it averaged only 0.66 larvae per plant (Table 2). In 1991, larvae first appeared on 25 June and population peaks were seen on 30 July, 20 August and 10 September (Fig. 1d) with an average of $0.90,2.13$ and 1.48 larvae per plant, respectively. A total of 451 larvae $(97 \%)$ were recorded from 432 broccoli during 23 July - 18 September, for an average of 1.03 larvae per plant, while only 12 larvae (3\%) were counted on 270 plants from 5 June to 16 July for an average of 0.04 larvae per plant. Pupal peaks were recorded on 23 July, 20 August and 10 September. Larval and pupal peaks occurred at approximately the same time in 1990 and 1991 even though populations in 1991 were smaller.

Three generations of this pest have been reported from Virginia (Lasota and Kok 1989) while four to five generations have been reported from Ontario (Butts and McEwen 1981; Harcourt 1985). There seems to be at least four population peaks on broccoli in southeastern New Brunswick with the later peaks yielding larger populations (Figs. 1c, 1d). Three to four generations were recorded by Godin and Boivin (1998) on cole crops in southwestern Quebec where a mean $352.7 \mathrm{DD}_{73}$ is required for one generation and $1315 \mathrm{DD}_{7.3}$ for four generations. Using DD accumulations calculated starting 1 January, $90 \%$ of all our specimens were collected before $1110 \pm 119.6 \mathrm{DD}_{7.3}$ or 5 September \pm 16.5 (P. Maltais, unpublished data). Therefore, there is time during the growing season for diamondback moth to develop four generations in New Brunswick. According to Butts and McEwen (1981) and Harcourt (1957), the diamondback moth does not overwinter in Canada. Dosdall (1994), however, has found evidence that this insect can overwinter in Alberta. In New Brunswick, no evidence of overwintering has yet been found. According to Talekar and Shelton (1993), this insect had become, in recent yr, the most destructive pest of crucifers throughout the world. Because of the small numbers observed, it is difficult, for the moment, to classify this insect as a major pest of cole crops in southeastern New Brunswick. However, since the diamondback moth does contribute to the excessive damage that occurs on broccoli and other cruciferous vegetables in this region, it bears careful monitoring during the growing season. This attention is also warranted by the ability of the diamondback moth to increase very rapidly and to develop resistance to all classes of insecticides including Bacillus thuringiensis ssp. kurstaki Berliner (Zhao and Grafius 1993). According to Anciso and Quick (1990) and Talekar and Shelton (1993), this has resulted in diamondback moth populations causing severe losses in cole crop production worldwide and requiring huge annual costs in management.

\section{Cabbage looper}

Even though the cabbage looper is a serious pest of cole crops in many parts of the world (Sears et al. 1983; Workman et al. 1980; Wyman and Oatman 1977), populations were much smaller than those of either the imported cabbageworm or the diamondback moth in 1990 and 1991. In 1990, only four eggs and 24 larvae were recorded from 1474 broccoli for an average of 0.003 and 0.02 individuals per plant, respectively 
(Table 2). The insect was first noticed on 13 August and 17 of the 24 larvae were sampled on 27 August for an average of 0,43 larvae per plant for that date (Fig. 1e).

In 1991, only 10 eggs were found of which seven were seen on 23 July (Fig. 1f). Only 37 larvae were sampled throughout the season (Fig. 1f) for an average of 0.05 individuals per plant (Table 2). However, the pattern of distribution was different than in 1990 (Figs. 1e, 1f). Larvae were first recorded on 23 July and throughout the growing season until 18 September but in negligible numbers. No pupae were seen in 1990 nor in 1991.

Extremely low populations of cabbage looper in New Brunswick is not surprising. According to Kirby and Slosser (1984) this species is more of a warm-season pest, being limited by cool, wet weather (Greene 1972) often encountered in this province. The other two pests, though, can attain high populations under cooler conditions.

Because of the inconsistencies of its initial appearance in our study and low population numbers, it is difficult to establish the number of generations for the cabbage looper in New Brunswick. According to Stewart and Harcourt (1994) there are three generations of this insect in southwestern Ontario where the climate is warmer and one generation in most other regions of the country.

\section{Early planting versus late planting}

With numbers expressed as CLE, lepidopteran populations on broccoli tend to peak from the latter part of July after being very low in the first part of the growing season (Figs. 2a, 2b). Mean CLE per wk increased the later the crops were transplanted.

The economic threshold for broccoli has been set at 1 CLE per plant per wk in New Brunswick (Maltais et al. 1994). In an insect management program, insecticides are applied when the threshold is reached. This threshold was reached during the first wk of August 1990 (Fig. 2a) and in the last wk of July in 1991 (Fig. 2b). In 1990, the first crop was harvested on 24 July and in 1991, on 29 July. Both crops had relatively low mean CLE per plant per wk during the growing period (Table 1) that would not have required any insecticide since the economic threshold was never reached except in 1991 during the last wk of growth, too close to harvest for an insecticide treatment.

Even though populations were much higher with a mean CLE per plant per wk of 0.471 (Table 1), the second crop of 1990 planted on 22 June and harvested on 9 August would not have required
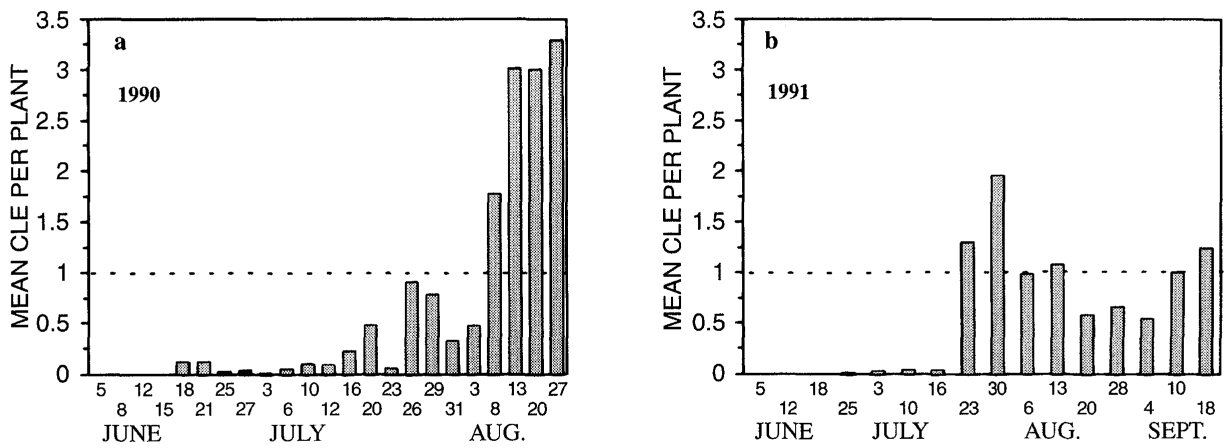

Figure 2. Mean populations of lepidopterous larvae on broccoli (a : 1990; $b$ : 1991), expressed as cabbage looper equivalents (CLE) per plant in southeastern New Brunswick. Dashed lines indicate threshold. 
spraying. The third crop of 1990 and the second and third one of 1991 would all have required spraying because the economic threshold was reached during the growth of the plants (Table 1, Figs. 2a, 2b).

Lower populations on early broccoli plantings could be explained, in part, by the fact that only the imported cabbageworm overwinters in the province while the other two migrate from warmer climates. Using prevailing winds from southern states, the diamondback moth can appear early in the spring in New Brunswick while the cabbage looper will be seen much later in July or August (Stewart and Harcourt 1994; Stewart and Jaques 1994). The imported cabbageworm, which is present even sooner, and the diamondback moth can feed on wild Cruciferae in the absence of cultivated crops such as broccoli (Lasota and Kok 1989). Since host preference is related to the growth stage of the plant (Lasota and Kok 1989), such Cruciferae can be strong competitors to broccoli seedlings. With various food sources available and with low insect populations, since natural population increase has not yet occurred, fewer specimens will be found on cultivated crops early in the season, making this complex easier to manage. It would benefit the growers to plant their crops as soon as possible in the spring, thus minimizing insecticide use and lessening production costs.

An understanding of seasonal occurrence and abundance of these pests will contribute to the development of better integrated management programs in New Brunswick.

\section{ACKNOWLEDGMENTS}

We thank M. Caissie, N. Caissie, G. Cormier, J. Landry, S. LeBlanc, A. Noël and $C$. Ouellette for their technical assistance. Thanks are also extended to C. LeBlanc and G. R. Thébeau (New Brunswick Department of Agriculture and Rural Development) for their able assistance in this study. Support for this research was provided by a grant from the Canada - New Brunswick Cooperation Agreement on Agri-Food Development project No. B6001-R1. Extensive support was also provided by Agriculture and Agri-Food Canada, by the New Brunswick Department of Agriculture and Rural Development and by the Université de Moncton.

\section{REFERENCES}

Anciso, J.R., and T.C. Quick. 1990. Parasitoids of the diamondback moth, Plutella xylostella (L.) in the Lower Rio Grande Valley, Texas. J. Rio Grande Valley Hortic. Soc. 43 : 89-90.

Andaloro, J.T., A.M. Shelton, and C.J. Eckenrode. 1982. Seasonal abundance of lepidopterous larvae in commercial cabbage fields. Environ. Entomol. 11 : 144146.

Butts, R.A., and F.L. McEwen. 1981. Seasonal populations of the diamonback moth, Plutella xylostella (Lepidoptera: Plutellidae), in relation to day-degree accumulation. Can. Entomol. 113 : 127-131.

Cranshaw, W.S., and R.J. Default. 1985. Effects of artificial defoliation on broccoli yield. Great Lakes Entomol. 18 : 55-57.

Dosdall, L.M. 1994. Evidence for successful overwintering of diamondback moth, Plutella xylostella (L.) (Lepidoptera: Plutellidae), in Alberta. Can. Entomol. 126 : 183-185.

Godin, C., and G. Boivin. 1998. Seasonal occurrence of lepidopterous pests of cruciferous crops in southwestern Quebec in relation to degree-day accumulations. Can. Entomol. 130 : 173-185.

Greene, G.L. 1972. Economic damage threshold and spray interval for cabbage looper control on cabbage. J. Econ. Entomol. $65: 205-208$.

Hamilton, J.T. 1979. Seasonal abundance of Pieris rapae (L.), Plutella xylostella (L.) and their diseases and parasites. Gen. Appl. Entomol. 11 : 59-65.

Harcourt, D.G. 1957. Biology of the diamondback moth, Plutella maculipennis (Curt.) (Lepidoptera: Plutellidae), in eastern Ontario. II. Life history, behaviour, and host relationships. Can. Entomol. 89 : 554-564.

Harcourt, D.G. 1985. Population dynamics of the diamondback moth in southern Ontario. Pages 3-23 in Talekar, N.S., and T.G. Griggs (eds.), Proceedings of the First International Workshop on Diamondback Moth Management. Asian Vegetable Research and Development Center Publications 86-248, Thailand. 
Harcourt, D.G., R.H. Backs, and L.M. Cass. 1955. Abundance and relative importance of caterpillars attacking cabbage in eastern Ontario. Can. Entomol. 87 : 400-406.

Hoy, C.W., A.M. Shelton, and J.T. Andaloro. 1986. Action thresholds for processing cabbage, a short-term solution to a longterm problem. Agric. Ecosyst. Environ. $16: 45-54$.

Kirby, R.D., and J.E. Slosser. 1984. Composite economic threshold for three lepidopterous pests of cabbage. J. Econ. Entomol. $77:$ 725-733.

Lasota, J.A., and L.T. Kok. 1989. Seasonal abundance of imported cabbageworm (Lepidoptera: Pieridae), cabbage looper (Lepidoptera: Noctuidae), and diamondback moth (Lepidoptera: Plutellidae) on cabbage in southwestern Virginia. J. Econ. Entomol. 82 : 811-818.

Maltais, P.M., J.R. Nuckle, and P.V. LeBlanc. 1994. Economic threshold for management of lepidopterous larvae on broccoli in southeastern New Brunswick. J. Econ. Entomol. 87 : 766-774.

Maltais, P.M., J.R. Nuckle, and P.V. LeBlanc. 1998. Economic threshold for three lepidopterous larval pests of fresh-market cabbage in southeastern New Brunswick. J. Econ. Entomol. 91 : 699-707.

Sears, M.K., R.P. Jaques, and J.E. Laing. 1983. Utilization of action thresholds for microbial and chemical control of lepidopterous pests (Lepidoptera: Noctuidae, Pieridae) on cabbage. J. Econ. Entomol. 76 : 368-374.

Sears, M.K., A.M. Shelton, T.C. Quick, J.A. Wyman, and S.E. Webb. 1985. Evaluation of partial plant sampling procedures and corresponding action thresholds for management of Lepidoptera on cabbage. J. Econ. Entomol. 78 : 913-916.

Stewart, J.G. 1990. Action thresholds for leaf-feeding insects of broccoli. Agriculture Canada Canadex. Horticultural crops. Publ. 252.251. 1 p.
Stewart, J.G., and D.G. Harcourt. 1994. Fausse-teigne des crucifères. In Richard, C. and G. Boivin. 1994. Maladies et ravageurs des cultures légumières au $\mathrm{Ca}$ nada. Soc. Can. Phytopathol. et Soc. Entomol. Can. Ottawa, Canada. 590 pp.

Stewart, J.G., and R.P. Jaques. 1994. Faussearpenteuse du chou. In Richard, C. and G. Boivin. 1994. Maladies et ravageurs des cultures légumières au Canada. Soc. Can. Phytopathol. et Soc. Entomol. Can. Ottawa, Canada. 590 pp.

Stewart, J.G., and M.K. Sears. 1988. Economic threshold for three species of lepidoptera larvae attacking cauliflower grown in southern Ontario. J. Econ. Entomol. $81: 1726-1731$.

Talekar, N.S., and A.M. Shelton. 1993. Biology, ecology and management of the diamondback moth. Annu. Rev. Entomol. 38 : 275-301.

Vail, K.M., L.T. Kok, and M. Lentner. 1989. Broccoli yield response to selected levels of cabbage looper (Lepidoptera: Noctuidae) larvae in southwestern Virginia. J. Econ. Entomol. 82 : 1437-1443.

Workman, R.B., R.B. Chalfant, and D.J. Schuster. 1980. Management of the cabbage looper and diamondback moth on cabbage by using two damage thresholds and five insecticide treatments. J. Econ. Entomol. 73 : 757-758.

Wyman, J.A., and F.R. Oatman. 1977. Yield responses in broccoli plantings sprayed with Bacillus thuringiensis at various lepidopterous larval density treatment levels. J. Econ. Entomol. 70 : 821-824.

Zhao, J.Z., and E. Grafius. 1993. Assessment of different bioassay techniques for resistance monitoring in the diamondback moth (Lepidoptera: Plutellidae). J. Econ. Entomol. 86 : 995-1000. 